\title{
EFFECT OF THE COOLING SYSTEM AND 1-MCP ON THE INCIDENCE OF SUPERFICIAL SCALD IN 'GRANNY SMITH’APPLES
}

\author{
Claudia Moggia ${ }^{1 *}$, Omar Hernández ${ }^{1}$, Marcia Pereira1, Gustavo A. Lobos ${ }^{1}$, and José Antonio Yuri'
}

\begin{abstract}
A study was carried out to determine the effects of two cooling systems and the application of 1-methylcyclopropene (1-MCP, SmartFresh ${ }^{\mathrm{TM}}$ ) on the incidence of superficial scald in apples (Malus domestica Borkh.) cv. Granny Smith. Fruit were collected from a commercial orchard (Colbún, Maule Region, Chile) during 2004-2005 season. A completely randomized design was used in a $2 \times 2$ factorial arrangement, using cooling systems (normal and step-wise cooling $)$ and application of 1-MCP $\left(0\right.$ and $625 \mathrm{~nL} \mathrm{~L}^{-1}$ i.a. $)$ as the main factors. Fruit from normal cooling were kept at $0{ }^{\circ} \mathrm{C}$ throughout the storage period (180 days). Step-wise cooling consisted of storing the fruit at $10{ }^{\circ} \mathrm{C}$ for 10 days; 4 ${ }^{\circ} \mathrm{C}$ for the next 20 days and $0{ }^{\circ} \mathrm{C}$ for the remaining 150 days. Every month, maturity indices and the chemicals, global antioxidant content (AO), $\alpha$-farnesene (AF) and conjugated trienes (TC), were measured. Incidence of superficial scald was determined after 180 days of storage, plus 10 days at $20^{\circ} \mathrm{C}$. The application of 1-MCP with both cooling systems was capable of maintaining firmness values around $8.2 \mathrm{~kg}$ up to the end of the storage period, as well as decreasing the concentration of AF, TC and AO during storage. Incidence of superficial scald on fruit with 1-MCP was $0 \%$, regardless of the type of cooling. Among treatments without 1-MCP, step-wise-cooling was more effective in preventing superficial scald, resulting in $1.3 \%$ incidence compared to $75.6 \%$ with the normal cooling system. Nevertheless, from the fourth month onwards firmness was lower than that required for export.
\end{abstract}

Key words: conjugated trienes, antioxidants, $\alpha$-farnesene, 1-methylcyclopropene, physiological disorder, ethylene.

\section{INTRODUCTION}

The apple represents the second most important fruit in Chile, with 37000 ha under cultivation, of which 9000 ha are dedicated to the cultivation of cv. Granny Smith (VII Censo Nacional Agropecuario y Forestal, 2007); with 7.3 million boxes exported during the 2004-2005 season (Alcaíno et al., 2007).

A series of physiological disorders can develop or are expressed during apple storage, superficial scald being one of the main disorders in cv. Granny Smith. This is a form of epidermal damage that does not compromise the flesh and is recognized by the presence of irregularly sized brown spots. Given that this alteration is induced by the low-temperature storage, it is accepted as a manifestation of chilling injury (Watkins et al., 1995). It has been demonstrated that superficial scald is associated with oxidation of $\alpha$-farnesene to conjugated trienes (Anet, 1972; Rowan et al., 2001; Arquiza et al., 2005; Isidoro and Almeida, 2006), which appear in greater concentrations, than just the accumulation of $\alpha$-farnesene at the end of

${ }^{1}$ Universidad de Talca, Facultad de Ciencias Agrarias, Casilla 747, Talca, Chile. *Corresponding author (cmoggia@utalca.cl).

Received: 23 May 2008.

Accepted: 15 july 2008. the storage period (Huelin and Coggiola, 1968; Meir and Bramlage, 1988; Whitaker et al., 2000).

Granny Smith apples have a high susceptibility to disorders, especially when they are harvested in an immature state (Ingle, 2001), given that the fruit will have lower antioxidant activity (Anet, 1974). Currently, scald is controlled effectively at the commercial level through the use of the synthetic antioxidant diphenylamine (DPA) (Golding et al., 2001; Watkins, 2003). However, this compound is considered an environmental contaminant and potentially harmful to health (Drzyzga, 2003). Because of probable restrictions on such products and the current tendency to employ alternatives that do not leave residuals that are dangerous to humans and to the environment, there is interest in studying new control methods.

Chapon (1981) suggested that progressive cooling of fruit during storage reduces the incidence of scald and proposed the use of $5{ }^{\circ} \mathrm{C}$ during the first month of storage, $2.5{ }^{\circ} \mathrm{C}$ in the second month, and $0{ }^{\circ} \mathrm{C}$ in the following months of storage. Nevertheless, it is important to determine the effect that an increase in temperature could have on the maturation of the fruit; in particular when extended storage is planned. At the same time, the compound 1-methylcyclopropene (1-MCP) is known to be 
a powerful inhibitor of ethylene action in the preclimateric phase. It delays the increased autocatalytic production of ethylene and consequently also delays fruit maturation. 1-MCP has proven to be an effective controller of scald (Fan and Mattheis, 1999; Rupashinge et al., 2000; Shaham et al., 2003; Zanella, 2003; Lurie et al., 2005). 1-MCP is sold commercially under the name of SmartFresh ${ }^{\mathrm{SM}}$ (AgroFresh, Rohm and Haas, Philadelphia, Pennsylvania, USA). The dosage used in apples is $625 \mathrm{~nL} \mathrm{~L}^{-1}$ (Blankenship and Dole, 2003; Watkins, 2006).

Considering the above, the following research was proposed with the objective of evaluating two systems of cooling (normal and step-wise) and the application of SmartFresh ${ }^{\mathrm{TM}}\left(0\right.$ and $625 \mathrm{~nL} \mathrm{~L}^{-1}$ i.a.), on the evolution of maturity and the development of superficial scald during the storage of cv. Granny Smith apples.

\section{MATERIALS AND METHODS}

\section{Vegetal material}

The study used 'Granny Smith' apples from an 8-yearold commercial orchard, on a self-dwarfing rootstock

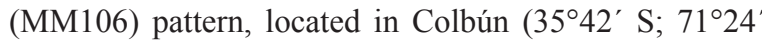
W), Maule Region, Chile.

\section{Treatment and storage of the fruit}

The fruit was collected on 8 April 2005 (201 days after full flowering) and were taken to the Post-Harvest Laboratory of the Pome Fruit Center of the Universidad de Talca, where the 1-MCP treatments $\left(0\right.$ and $625 \mathrm{~nL} \mathrm{~L}^{-1}$ i.a.) were applied and the cooling conditions (normal and step-wise) were established (Table 1). For the application of 1-MCP $\left(0.14 \%\right.$, SmartFresh ${ }^{\mathrm{TM}}$, AgroFresh, Rohm and Haas, Philadelphia, Pennsylvania, USA) the fruit was cooled to 0 and $10{ }^{\circ} \mathrm{C}$, according to whichever corresponded, and placed in sealed acrylic chambers of $0.3 \mathrm{~m}^{3}$, in order to be treated with a dose of $625 \mathrm{~nL} \mathrm{~L}^{-1}$ i.a., for $24 \mathrm{~h}$. The compound was applied in gaseous form by dissolving SmartFresh ${ }^{\mathrm{TM}}(0.14 \% 1-\mathrm{MCP})$ in warm water $\left(30-40{ }^{\circ} \mathrm{C}\right)$. Immediately after the treatments the fruit was returned to cooling conditions, together with fruit without treatment.

\section{Evaluations}

The following variables were evaluated at harvest, and at monthly removals from storage, using four replications with five apples each.

Firmness $(\mathrm{kg})$ was measured with a penetrometer mounted in a drill press (Effegi FT 327, McCormick Fruit Tech, Yakima, USA), an provided with an $11 \mathrm{~mm}$ diameter plunger tip. Two measurements were taken for each fruit in opposing sides of the equatorial region, after removing the peel.

Soluble solids ( ${ }^{\circ}$ Brix) were evaluated with a thermocompensated refractometer (Atago ATC 1, Tokyo, Japan) from an extract of juice from each fruit.

Starch index was determined by applying an iodine solution (iodine at $0.1 \%$ dissolved in potassium iodine at $30 \%$ ) to transversal cuts of fruit, and then comparing the intensity and pattern of black-blue coloration, using a scale of 1 (zero starch degradation) to 6 (maximum starch degradation), specific for cv. Granny Smith apples (Asociación de Exportadores de Chile, 1997).

\section{Extraction of epidermal compounds}

The same fruit were used for determining epidermal compounds and maturity indexes. The epidermal compounds that were determined were: global antioxidant content (AO), $\alpha$-farnesene concentration (AF) and concentration of conjugated trienes (TC). Tissue extraction and AF and TC analyses were carried out according to Anet (1972), with modifications similar to those used by Isidoro and Almeida (2006). Using a punch tool, of $0.8 \mathrm{~cm}^{2}$ disks of peel were removed from the equatorial region of the each fruit. The disks were submerged in $25 \mathrm{~mL}$ of $\mathrm{n}$-hexane (Merck, Darmstadt, Germany), for $3 \mathrm{~min}$. Aliquots of this solution were analyzed in a spectrophotometer (Milton Roy 1201, Milton Roy, New York, USA), registering absorbancy at $232 \mathrm{~nm}$ (AF) and 258, 269, 281 and $290 \mathrm{~nm}$ (TC). For AF, a molar extinction coefficient of 29000 was used, according to the methodology proposed by Anet (1972). For the TC, the absorption peaks OD281-290, OD258-290 and OD269290 were calculated, expressed as TC281, TC258 and TC269, respectively; the extinction coefficient used was

Table 1. Treatments applied to 'Granny Smith' apples at harvest (8 April, 2005). Colbún, Maule Region, Chile.

\begin{tabular}{lccc}
\hline Type of cooling & Temperature & Duration & 1-MCP dosage \\
\hline & ${ }^{\circ} \mathrm{C}$ & $\mathrm{d}$ & $\mathrm{nL} \mathrm{L}{ }^{-1}$ a.i. \\
Normal & 0 & 180 & 0 \\
& & & 625 \\
Step-wise & 10 & 10 & 0 \\
& 4 & 20 & 625 \\
\hline
\end{tabular}


25000 (Anet, 1972; Du and Bramlage, 1993). These compounds were expressed in $\mathrm{nmol} \mathrm{cm} \mathrm{cm}^{-2}$ based on fresh weight. The antioxidant content was estimated globally through readings at $200 \mathrm{~nm}$ of the same solution of $\mathrm{n}$-hexane, and was expressed as OD $1000 \mathrm{~cm}^{-2}$ of peel, according to the methodology proposed by Meir and Bramlage (1988) and used by Thomai et al. (1998) and Diamantidis et al. (2002).

\section{Evaluation of superficial scald}

The incidence (\%) of superficial scald was determined visually, using 200 apples, distributed in four replications of 50 fruit each one. The number of fruit affected after 6 months of storage plus 10 days at room temperature (20 ${ }^{\circ} \mathrm{C}$ ) was determined. The period for scalding evaluation was defined according to previous experience that demonstrated a maximum expression of disorder in this period (Moggia et al., 2003)

\section{Design and statistical analysis}

The experiment was conducted with a completely randomized design in a factorial arrangement of $2 \times 2$, given by two types of cooling and two doses of 1-MCP, generating a total of four treatments. The results were submitted to analysis of variance (ANOVA) to establish possible differences among treatments. Prior to the ANOVA, the data in percentages were transformed into the $\arcsin \left(\%{ }^{1 / 2}\right)$ function. When there were differences among treatments, mean separation was conducted using the least significant difference test (LSD, $\mathrm{p} \leq 0.05$ ). Given that practically all the variables analyzed presented significance in the interaction of both factors, the four treatments were analyzed separately. The computer software Statgraphics Plus V 4.0 professional (Manugistics, Maryland, USA) was used for all the analysis.

\section{RESULTS AND DISCUSSION}

The initial condition of the fruit at harvest (Table 2) met with the requirements for the application of 1-MCP in 'Granny Smith' apples, according to the technical requirements of AgroFresh, Chile; namely, starch 1.8 to 3.5 , on a scale of 1 to 6 ; and a minimal firmness of $7.3 \mathrm{~kg}$ (SmartFresh, 2006).

\section{Evolution of maturity index}

Until 90 days of storage the decrease in firmness of the fruit was minimal in all of the treatments, except in those with step-wise cooling and without 1-MCP (Figure 1). At 30 days the latter began exhibiting lower values of the index, a tendency that continued until the end of the storage. The application of 1-MCP, independent of the type of cooling, significantly inhibited the softening
Table 2. Maturity indexes and chemical compounds of 'Granny Smith' apples peel at harvest (8 April 2005), Colbún, Maule Region, Chile. Season 2004-2005.

\begin{tabular}{lc}
\hline Variable & Value \\
\hline Maturity index & \\
Firmness, kg & 8.2 \\
Starch index (scale 1-6) & 3.0 \\
Compounds related to superficial scald & \\
$\mathrm{AO}^{\mathrm{a}}, \mathrm{OD} 1000 \mathrm{~cm}^{-2}$ & 42.7 \\
$\mathrm{AF}^{\mathrm{b}}, \mathrm{nmol} \mathrm{cm}^{-2}$ & 6.4 \\
$\mathrm{TC}_{258}$, nmol cm & \\
$\mathrm{TC} 269^{\mathrm{d}}, \mathrm{nmol} \mathrm{cm}^{-2}$ & 2.9 \\
$\mathrm{TC} 281^{\mathrm{e}}, \mathrm{nmol} \mathrm{cm}^{-2}$ & 1.9 \\
\hline
\end{tabular}

${ }^{\mathrm{a}} \mathrm{AO}$ : global antioxidant content measured at a wavelength of $200 \mathrm{~nm}$. bAF: alfa-farnesene, measured at a wavelength of $232 \mathrm{~nm}$.

${ }^{\circ}$ TC 258: Conjugated trienes measured at a wavelength of $258 \mathrm{~nm}$. 'TC 269: Conjugated trienes measured at a wavelength of $269 \mathrm{~nm}$. 'TC 281: Conjugated trienes measured at a wavelength of $281 \mathrm{~nm}$.

of the fruit, resulting in firmness close to $8.2 \mathrm{~kg}$, up to 6 months of storage. In the same period, the firmness of treatments without 1-MCP reached $6.5 \mathrm{~kg}$ (normal cooling) and $5.7 \mathrm{~kg}$ (step-wise cooling). According to these results, fruit with step-wise cooling and without 1-MCP would be below the minimal firmness requirement for export, from the fourth month of storage, given that the limit established by the Exporters Association of Chile is $5.9 \mathrm{~kg}$. Numerous investigations support the view that 1-MCP, as an inhibitor of ethylene action, acts on those dependent indices of this hormone, such as firmness, with the result of less softening of the fruit. This effect also extends subsequent shelf-life (Fan et al., 1999; Watkins et al., 2000; Mir et al., 2001; DeEll et al., 2002; 2005; Zanella, 2003; DeLong et al., 2004; Bai et al., 2005).

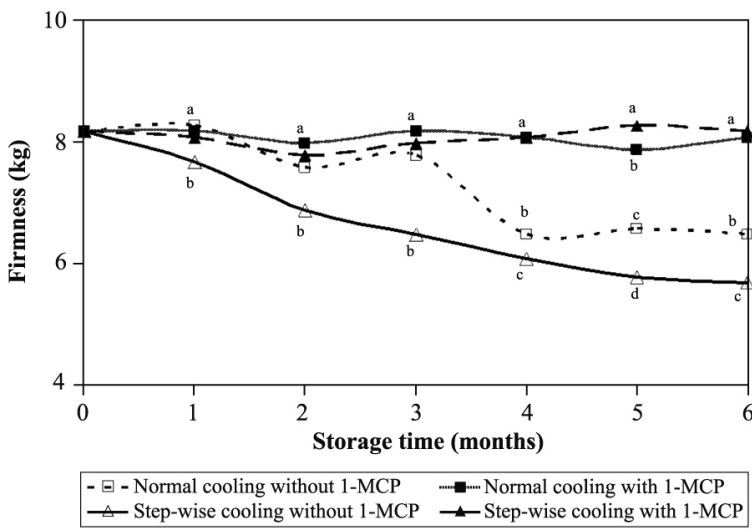

Figure 1. Effect of cooling system (normal and step-wise) and 1-MCP dosage (0 and $625 \mathrm{~nL} \mathrm{~L}^{-1}$ active ingredient) on firmness of 'Granny Smith' apples after 6 months of refrigerated storage. 
The greater slope in the decrease in firmness in the treatment with step-wise cooling and without $1-\mathrm{MCP}$ is explained by the higher initial temperature to which the fruit was exposed, given that there is a direct relationship between this factor and softening (Mir et al., 2001). Normal cooling without 1-MCP also showed a decrease in firmness. However, the major decrease was produced after month 3; which indicates that low temperature delays the maturation process but does not completely inhibit it.

The concentration of soluble solids remained relatively stable during storage and without major variations in function of the treatments applied; the values fluctuated between 11.7 and $13.0{ }^{\circ}$ Brix (data not shown). Starch degradation increased continuously until reaching a maximum level (6) at month 3 for fruit with all treatments (data not shown). In this respect, numerous studies on apples indicate that soluble solids and starch degradation are not affected by the application of 1-MCP (Fan et al., 1999; Rupashinge et al., 2000; Zanella, 2003; DeLong et al., 2004; DeEll et al., 2005).

\section{Chemical compounds and the incidence of superficial scald}

The higher $\mathrm{AO}$ values were observed in fruit of both types of cooling without 1-MCP application (Figure 2A), reaching its maximum level in month 5 . As well, between these two treatments, more $\mathrm{AO}$ content was found in fruit with step-wise cooling. According to Bramlage et

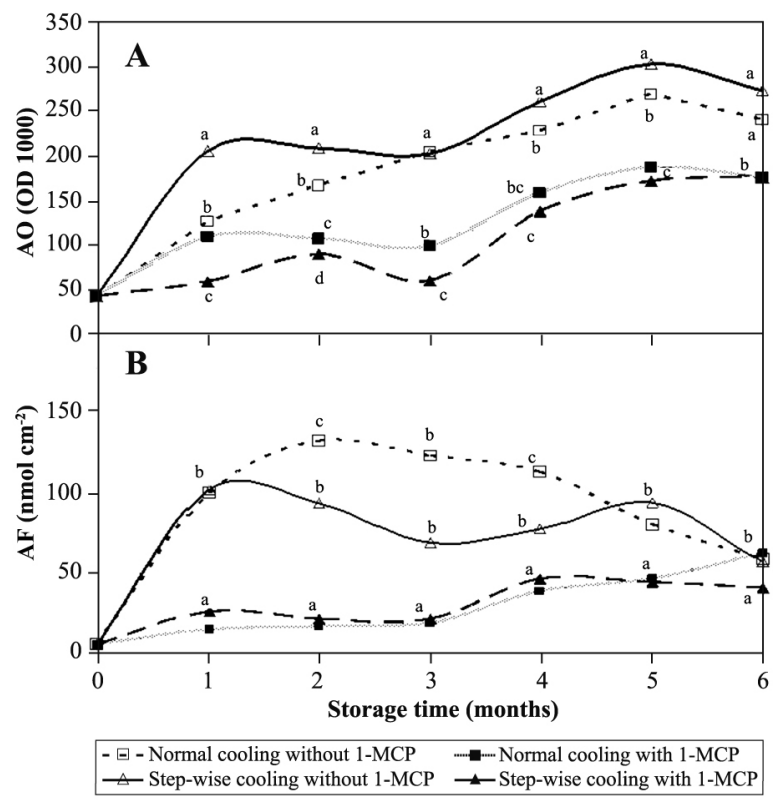

Figure 2. Effect of cooling system (normal and step-wise) and 1-MCP dosage ( 0 and $625 \mathrm{~nL} \mathrm{~L}^{-1}$ active ingredient) on (A) antioxidant capacity (AO) and (B) $\alpha$-farnesene concentration (AF) of Granny Smith apples after 6 months of refrigerated storage. al. (1993), the increase in antioxidants is related to the advance in the maturity of the fruit and not to the levels of liposoluble antioxidants able to counteract the effects of conjugated trienes. In this way, the delay in maturity provoked by the application of 1-MCP is reflected in the lower $\mathrm{AO}$ content obtained in these treatments.

The greatest synthesis of $\mathrm{AF}$ occurred in fruit with normal cooling without 1-MCP (Figure 2B), reaching the maximum concentration at 60 days of storage, product of its oxidation into TC (Huelin and Coggiola, 1968; Meir and Bramlage, 1988; Whitaker et al., 1997; Pechous et al., 2005). Effectively, the increase of TC in this treatment began in month 2 and was distinct from the other treatments until the end of the storage period. This affirms the theory that identifies $\mathrm{AF}$ as the indirect precursor of superficial scald and the results are in agreement with those described by several authors (Huelin and Coggiola, 1968; Barden and Bramlage, 1994; Whitaker et al., 1997; Shaham et al., 2003). Gradual cooling of the fruit by itself resulted in reducing $\mathrm{AF}$ accumulation beginning at 30 days of storage; this lower availability of AF could be responsible for the drastic reduction in scald that was observed in this treatment $(1.3 \%)$. The application of $1-\mathrm{MCP}$ was very effective in reducing AF levels with no differences between the two types of cooling. Golding et al. (2001) and Lurie et al. (2005) demonstrated that ethylene is necessary for the synthesis of $\alpha$-farnesene; from which it is understood that the application of 1-MCP is capable of inhibiting $\alpha$-farnesene formation. The lower concentration of AF in the treatments with 1-MCP agrees with lower TC accumulation and zero incidence of scald (Table 3 ).

$\mathrm{TC}$ are generated as a product of the oxidation of $\mathrm{AF}$ during the storage of apples and have been identified as the direct cause of cellular damage that leads to the expression of scalding symptoms (Whitaker et al., 1997; Rowan et al., 2001). The application of 1-MCP to fruit with normal and step-wise cooling resulted in significantly lower levels of TC 258; 269 and 281 in comparison to fruit without treatment, throughout all the evaluations (Figure 3A, 3B and $3 \mathrm{C}$ ). This was expected, given the reduction in $\mathrm{AF}$ provoked by the application of 1-MCP. For fruit without 1-MCP, step-wise cooling resulted in higher values of TC 258 and TC 269 in the first months in comparison to normal cooling. This behavior supports what was proposed by Du and Bramlage (1993) and Whitaker (1998), in the sense that these trienes play a protective rather than conductive role in the development of scald. According to Anet and Coggiola (1974) the evolution of TC 281 is the most associated with scald. In this research there was a clear differentiation in TC 281 levels according to the treatments: the lower concentrations were registered in fruit with 1-MCP (normal and stepwise cooling), while the highest concentrations were in 


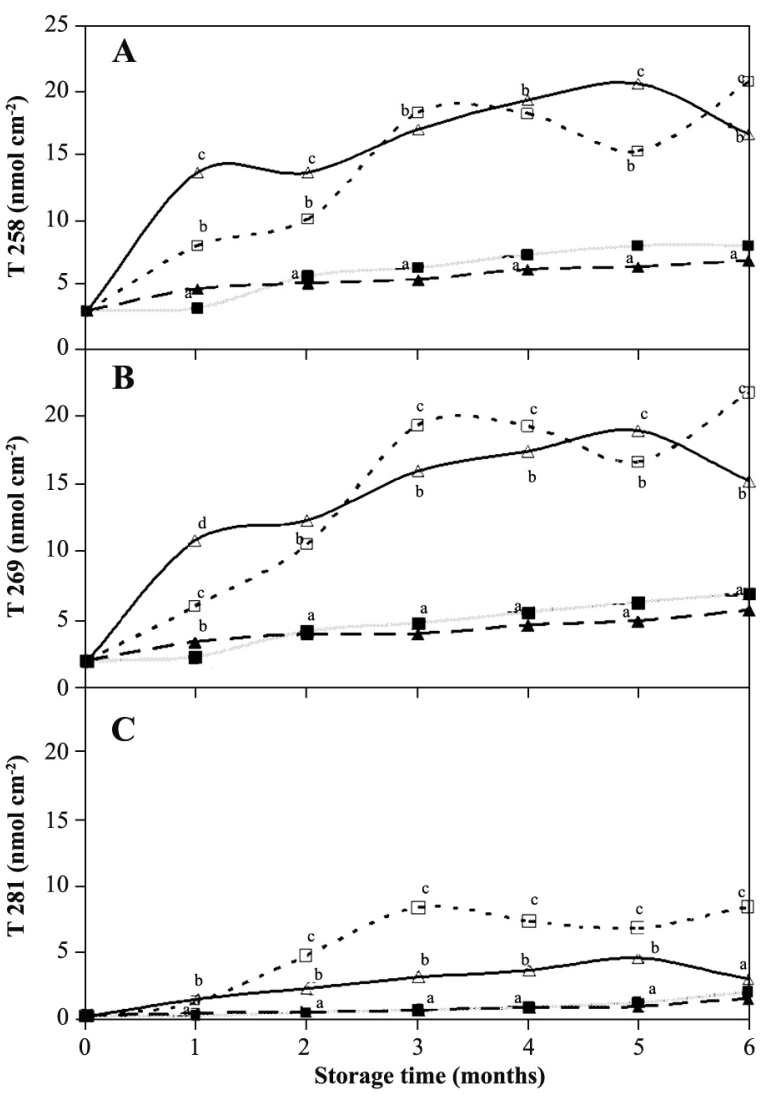

- $\square$ - Normal cooling without 1-MCP …-m...-Normal cooling with 1-MCP $\simeq$ Step-wise cooling without $1-\mathrm{MCP} \_$Step-wise cooling with 1-MCP

Figure 3. Effect of cooling system (normal and step-wise) and 1-MCP dosage ( 0 and $625 \mathrm{~nL}^{-1}$ active ingredient) on (A) conjugated trienes concentration TC 258, (B) TC 269 and (C) TC 281 of 'Granny Smith' apples after 6 months of refrigerated storage.

fruit with normal cooling without 1-MCP; an intermediate situation occurred in fruit with step-wise cooling without 1-MCP. Thus, high levels of TC 281 are related to the development of superficial scald, given that they evolve in a similar manner to AF. In accordance with these results, the incidence of superficial scald was minimal for the treatment with 1-MCP and step-wise cooling (0 and $1.3 \%$, respectively) and close to $80 \%$ for fruit with normal cooling (Table 3).

In a complementary manner, the levels of $\mathrm{AF}, \mathrm{TC}$ and $\mathrm{AO}$ at removal from 1, 2 and 3 months of storage, were correlated with the final incidence of scald (6 months plus 10 days at $20^{\circ} \mathrm{C}$ ). The highest levels of association were given for TC 281, showing as well, that the only significant association occurred in month $3(\mathrm{r}=0.95$, Table 4). Measurement of this compound can represent a predictive element for the final incidence of the disorder and a tool for decision-making about the re-application of antioxidant. This practice is currently used commercially and has shown its highest efficiency between the second and third month of storage (Moggia et al., 2003). Given the results of this research, levels of TC281 below 4 nmol $\mathrm{cm}^{-2}$, after 3 months of storage, would considerably reduce the risk of developing scalding in the fruit. In contrast, with higher levels it would be recommendable to make another application. The associations for $\mathrm{AF}$ and $\mathrm{AO}$ resulted in low and not significant values, which suggests that more specific measurement techniques are needed, in particular in the case of AO.

If we accept that superficial scald in cv. Granny Smith apples is caused by low temperature (Watkins et al., 1995), an increase in the storage temperature would reduce its incidence. This coincides with the results obtained in this research, given that independent of 1-MCP application, there was a low incidence of scald in step-wise cooling $(1.3 \%)$. On the contrary, normal cooling resulted in a higher incidence of the disorder when not applying 1-MCP.

1-MCP was an efficient controller of superficial scald throughout the storage period. This agrees with what has been reported by several studies (Fan et al., 1999; Watkins et al., 2000; DeEll et al., 2002; Shaham et al., 2003; Zanella, 2003; DeLong et al., 2004) and reaffirms that the control is a function of an inhibition of ethylene that regulates lower AF production (Fan and Mattheis, 1999; Watkins et al., 2000; Golding et al., 2001; Shaham

Table 3. Effect of cooling system (normal and step-wise) and 1-MCP dosage ( 0 and $625 \mathrm{~nL} \mathrm{~L}^{-1}$ active ingredient) on superficial scald incidence' ${ }^{1}$ in 'Granny Smith' apples after 6 months of refrigerated storage plus 10 days at room temperature $\left(20^{\circ} \mathrm{C}\right)$.

\begin{tabular}{lc}
\hline Factor & Incidence \\
\hline Cooling & $\%$ \\
Normal & 37.8 \\
Step-wise & 0.6 \\
Significance & $* *$ \\
1-MCP, nL L ${ }^{-1}$ a.i. & \\
0 & 38.4 \\
625 & 0.0 \\
Significance & $* *$ \\
Interaction & \\
Normal cooling without 1-MCP & $75.6 \mathrm{~b}$ \\
Normal cooling with 1-MCP & $0.0 \mathrm{a}$ \\
Step-wise cooling without 1-MCP & $1.3 \mathrm{a}$ \\
Step-wise cooling with 1-MCP & $0.0 \mathrm{a}$ \\
Significance & $* *$ \\
\hline
\end{tabular}

$* * \mathrm{p} \leq 0.01$

a.i.: active ingredient.

${ }^{1}$ Analysis based on transformed data $\left(\arcsin \left(\% \frac{1}{1 / 2}\right)\right)$.

Means in a column followed by the same letter do not differ statistically, according to the least significant difference test (LSD) $(\mathrm{p} \leq 0.05)$. 
Table 4. Correlation coefficient ( $r$ ) of chemical compounds (AO, AF, TC) and superficial scald incidence in 'Granny Smith' apples after 6 months of refrigerated storage plus 10 days at room temperature $\left(20^{\circ} \mathrm{C}\right)$.

\begin{tabular}{lcc}
\hline Chemical compound & Months in storage before chemical analysis & Correlation coefficient r \\
\hline $\mathrm{AO}^{\mathrm{a}}$ & 1 & $0.03 \mathrm{~ns}$ \\
& 2 & $0.29 \mathrm{~ns}$ \\
& 3 & $0.58 \mathrm{~ns}$ \\
$\mathrm{AF}^{\mathrm{b}}$ & 1 & $0.57 \mathrm{~ns}$ \\
& 2 & $0.79 \mathrm{~ns}$ \\
$\mathrm{TC} 258^{\mathrm{c}}$ & 3 & $0.89 \mathrm{~ns}$ \\
& 1 & $0.10 \mathrm{~ns}$ \\
$\mathrm{TC} 269^{\mathrm{d}}$ & 2 & $0.25 \mathrm{~ns}$ \\
& 3 & $0.65 \mathrm{~ns}$ \\
$\mathrm{TC} 281^{\mathrm{e}}$ & 1 & $0.07 \mathrm{~ns}$ \\
& 2 & $0.44 \mathrm{~ns}$ \\
& 3 & $0.72 \mathrm{~ns}$ \\
& 1 & $0.41 \mathrm{~ns}$ \\
\hline
\end{tabular}

aAO: global antioxidant content measured at a wavelength of $200 \mathrm{~nm}$. ${ }^{\mathrm{b}} \mathrm{AF}$ : $\alpha$-farnesene, measured at a wavelength of $232 \mathrm{~nm}$.

'TC 258: Conjugated trienes measured at a wavelength of $258 \mathrm{~nm}$.

et al., 2003; Arquiza et al., 2005; Tsantili et al., 2007) and its consequent oxidation of TC, in particular TC 281.

\section{CONCLUSIONS}

1-MCP was an efficient controller of superficial scald in cv. Granny Smith apples after 6 months of storage plus 10 days at room temperature $(0 \%$ of incidence). Step-wise cooling without $1-\mathrm{MCP}$ was also effective in controlling superficial scald, given that only $1.3 \%$ of the fruit presented the disorder, the firmness values were not adequate for exporting after 4 months of storage. The application of 1-MCP, independent of the type of cooling, maintained firmness values that were adequate for export throughout the storage period. The accumulation of compounds related to superficial scald (AO, AF and TC) was significantly lower in fruit with 1-MCP.

\section{RESUMEN}

Efecto del sistema de enfriamiento y 1-MCP sobre la incidencia de escaldado superficial en manzanas 'Granny Smith'. Se desarrolló un estudio para determinar el efecto de dos sistemas de enfriamiento y la aplicación de 1-metilciclopropeno (1-MCP, SmartFresh ${ }^{\mathrm{TM}}$ ) sobre la incidencia de escaldado superficial en manzanas (Malus domestica Borkh.) cv. Granny Smith, colectadas de un huerto comercial (Colbún, Región del Maule, Chile)
dTC.269: Conjugated trienes measured at a wavelength of $269 \mathrm{~nm}$. 'TC.281: Conjugated trienes measured at a wavelength of $281 \mathrm{~nm}$. ns: not significant. durante la temporada 2004-2005. El ensayo consistió en un diseño completamente al azar con arreglo factorial 2 x 2, usando sistema de enfriamiento (normal y lento) y aplicación de 1-MCP (0 y $625 \mathrm{~nL} \mathrm{~L}^{-1}$ i.a. $)$ como factores. Fruta con enfriamiento normal se mantuvo a $0{ }^{\circ} \mathrm{C}$ durante todo el período ( 180 días). El enfriamiento lento consistió en almacenar a $10{ }^{\circ} \mathrm{C}$ por 10 días, $4{ }^{\circ} \mathrm{C}$ por 20 días y 0 ${ }^{\circ} \mathrm{C}$ por los restantes 150 días. Mensualmente se evaluaron índices de madurez y compuestos químicos, contenido antioxidante global (AO), $\alpha$-farneseno (AF) y trienos conjugados (TC). La incidencia de escaldado superficial se determinó después de 180 días de almacenaje más 10 días a $20{ }^{\circ} \mathrm{C}$. La aplicación de 1-MCP, en ambos sistemas de enfriamiento, logró mantener valores de firmeza de alrededor de $8,2 \mathrm{~kg}$ hasta el fin del almacenaje y disminuir la concentración de AF, TC y AO durante la guarda. La incidencia de escaldado en fruta con 1-MCP fue $0 \%$, independiente del tipo de enfriamiento. Entre los tratamientos sin 1-MCP, el enfriamiento lento fue más efectivo en prevenir el desorden, presentando sólo 1,3\% de incidencia, respecto a $75,6 \%$ del enfriamiento normal. Sin embargo, la firmeza cayó bajo los estándares para exportación desde los cuatro meses.

Palabras clave: trienos conjugados, antioxidantes, $\alpha$-farneseno, 1-metilciclopropeno, desorden fisiológico, etileno. 


\section{LITERATURE CITED}

Alcaino, M., I. Quiroz, M. Nuñez, E. Salas, y P. González. 2007. Export data yearbook. p. 626. Asociación de Exportadores de Chile A.G. y Decofrut S.A. Quebecor World Chile S.A., Santiago, Chile.

Anet, E. 1972. Superficial scald, a functional disorder of stored apples. IX. Effect of maturity and ventilation. J. Sci. Food Agric. 23:763-769.

Anet, E. 1974. Superficial scald, a functional disorder of stored apples. XI. Apple antioxidants. J. Sci. Food Agric. 25:299-304.

Anet, E., and I. Coggiola. 1974. Superficial scald, a functional disorder of stored apples. X. Control of $\alpha$-farnesene autooxidation. J. Sci. Food Agric. 25:293-298.

Arquiza, J., A. Hay, J. Noch, and C. Watkins. 2005. 1-Methylcyclopropene (1-MCP) interactions with diphenylamine degradation, superficial scald metabolism, and polyphenol oxidase and peroxidase activities in apple fruit. J. Agric. Food Chem. 53:7565-7570.

Asociación de Exportadores de Chile. 1997. Fruta fresca chilena de exportación. Manual de productos y embalajes. Atenea Impresores, Santiago, Chile. ISBN 956-7694-00-1.

Bai, J., E. Baldwin, K. Goodner, J. Mattheis, and J. Brecht. 2005. Response of four apple cultivars to 1-methylcyclopropene treatment and controlled atmosphere storage. HortScience 40:1534-1538.

Barden, C.L., and W.J. Bramlage. 1994. Accumulation of antioxidants in apple peel as related to preharvest factors and superficial scald susceptibility of the fruit. J. Amer. Soc. Hort. Sci. 119:264-269.

Blankenship, S., and J. Dole. 2003. 1-Methylcyclopropene: a review. Postharvest Biol. Technol. 28:1-25.

Bramlage, W., C. Barden, and C. Watkins. 1993. Comparing potential predictors of scald susceptibility of apples (Malus domestica Borkh.). Acta Hort. (ISHS) 326:237-244.

Chapon, J. 1981. Choix des meilleures conditions de conservation de la pomme Granny Smith. Effet de la température et de la composition de l'atmosphère. Arboric. Fruit. 333:49-51.

DeEll, J., D. Murr, R. Mueller, L. Wiley, and M. Porteous. 2005. Influence of 1-methylciclopropene (1-MCP), diphenylamine (DPA), and $\mathrm{CO}_{2}$ concentration during storage on "Empire" apple quality. Postharvest Biol. Technol. 38:1-8.

DeEll, J., D. Murr, M. Porteous, and H. Rupasinghe. 2002. Influence of temperature and duration of 1-methylciclopropene (1-MCP) treatment on apple quality. Postharvest Biol. Technol. 24:349-353.
DeLong, J., R. Prange, and P. Harrison. 2004. The influence of 1-methylcyclopropene on 'Cortland' and 'McIntosh' apple quality following long-term storage. HortScience 39:1062-1065.

Diamantidis, G., T. Thomai, G. Genitsariotis, G. Nanos, N. Bolla, and E. Sfakiotakis. 2002. Scald susceptibility and biochemical/physiological changes in respect to low preharvest temperature in 'Starking Delicious' apple fruit. Sci. Hortic. (Canterbury, Engl.) 92:361-366.

Drzyzga, O. 2003. Diphenylamine and derivates in the environment: A review. Chemosphere 53:809-818.

Du, Z., and W. Bramlage. 1993. A modified hypothesis on the role of conjugated trienes in superficial scald development on stored apples. J. Amer. Soc. Hort. Sci. 118:807-813.

Fan, X., S. Blankenship, and J. Mattheis. 1999. 1-Methylcyclopropene inhibits apple ripening. J. Amer. Soc. Hort. Sci. 124:690-695.

Fan, X., and J.P. Mattheis. 1999. Development of apple superficial scald, soft scald, core flush, and greasiness is reduced by MCP. J. Agric. Food Chem. 47:30633068.

Golding, J., W. McGlasson, and S. Wyllie. 2001. Relationship between production of ethylene and $\alpha$-farnesene in apples, and how it is influenced by the timing of diphenylamine treatment. Postharvest Biol. Technol. 21:225-233.

Huelin, F., and I. Coggiola. 1968. Superficial scald, a functional disorder of stored apples. IV. Effect of variety, maturity, oiled wraps and diphenylamine on the concentration of $\alpha$-farnesene in the fruit. J. Sci. Food Agric. 19:297-301.

Ingle, M. 2001. Physiology and biochemistry of superficial scald of apples and pears. Hortic. Rev. 27:227-267.

Isidoro, N., and D. Almeida. 2006. $\alpha$-Farnesene, conjugated trienols, and superficial scald in 'Rocha' pear as affected by 1-methylcyclopropene and diphenylamine. Postharvest Biol. Technol. 42:49-56.

Lurie, S., A. Lers, Z. Shacham, L. Sonego, S. Burd, and B. Whitaker. 2005. Expression of $\alpha$-farnesene synthase AFS1 and 3-hydroxy-3-methylglutaryl coenzyme A reductase $H M G 2$ and $H M G 3$ in relation to $\alpha$-farnesene and conjugated trienols in 'Granny Smith' apples heat or 1-MCP treated to prevent superficial scald. J. Amer. Soc. Hort. Sci. 130:232-236.

Meir, S., and W. Bramlage. 1988. Antioxidant activity in 'Cortland' apple peel and susceptibility to superficial scald after storage. J. Amer. Soc. Hort. Sci. 113:412-418.

Mir, N., E. Curell, N. Khan, M. Whitaker, and R. Beaudry. 2001. Harvest maturity, storage temperature, and 1-MCP application frequency alter firmness retention and chlorophyll fluorescence of 'Redchief Delicious' apples. J. Amer. Soc. Hort. Sci. 126:618-624. 
Moggia, C., J.A. Yuri, M. Lolas, and M. Pereira. 2003. Use of thermofogging for DPA and fungicides applications in Chile. Washington Tree Fruit Postharvest Conference Proceedings, Wenatchee. 2-3 December. Washington State University, Tree Fruit Research and Extension Center (TFREC), Postharvest Information Network, Wenatchee, Washington, USA. Available at http://postharvest.tfrec.wsu.edu/PC2003G.pdf (accessed 15 May 2008).

Pechous, S., C. Watkins, and B. Whitaker. 2005. Expression of $\alpha$-farnesene gene AFS1 in relation to levels of $\alpha$-farnesene and conjugated trienols in peel tissue of scald-susceptible 'Law Rome' and scald-resistant 'Idared' apple fruit. Postharvest Biol. Technol. 35:125-132.

Rowan, D., M. Hunt, S. Fielder, J. Norris, and M. Sherburn. 2001. Conjugated triene oxidation products of $\alpha$-farnesene induce symptoms of superficial scald on stored apples. J. Sci. Food Chem. 49:2780-2787.

Rupashinge, H., D. Murr, G. Paliyath, and L. Skog. 2000. Inhibitory effect of 1-MCP on ripening and superficial scald development in 'McIntosh' and 'Delicious' apples. J. Hortic. Sci. Biotech. 75:271-276.

Shaham, Z., A. Lers, and S. Lurie. 2003. Effect of heat or 1-MCP on antioxidative enzyme activities and antioxidants in apples in relation to superficial scald development. J. Amer. Soc. Hort. Sci. 128:761-766.

SmartFresh. 2006. Recomendaciones de uso en manzanas. Chile. p. 4. SmartFresh, AgroFresh Inc., Santiago, Chile.

Thomai, T., E. Sfakiotakis, G. Diamantidis, and M. Vasilakakis. 1998. Effects of low preharvest temperature on scald susceptibility and biochemical changes in Granny Smith apple peel. Sci. Hortic. (Canterbury, Engl.) 76:1-15.

Tsantili, E., N. Gapper, J. Arquiza, B. Whitaker, and C. Watkins. 2007. Ethylene and $\alpha$-farnesene metabolism in green and red skin of three apple cultivars in response to 1-methylcyclopropene (1-MCP) treatment. J. Agric. Food Chem. 55:5267-5276.
VII Censo Nacional Agropecuario y Forestal. 2007. Resultados preliminares. Instituto Nacional de Estadística (INE), Oficina de Estudios y Políticas Agrarias (ODEPA), Ministerio de Agricultura, Santiago, Chile. Available at http://www. censoagropecuario.cl/index2.html (accessed 28 April 2008).

Watkins, C., W. Bramlage, and B. Cregoe. 1995. Superficial scald of 'Granny Smith' apples is expressed as a typical chilling injury. J. Amer. Soc. Hort. Sci. 120:88-94.

Watkins, C., J. Nock, and B. Whitaker. 2000. Responses of early-mid and late season apple cultivars to postharvest application of 1-methycyclopropene (1$\mathrm{MCP})$ under air and controlled atmosphere storage conditions. Postharvest Biol. Technol. 19:17-32.

Watkins, C. B. 2003. Principles and practices of postharvest handling and stress. p. 585-614. In: Feree, D., and I. Warrington (eds.) Apples: Crop physiology, production and uses. CABI Publishing, Wallingford, UK.

Watkins, C. 2006. The use of 1-methylcyclopropene (1MCP) on fruits and vegetables. Biotechnol. Adv. 24: 389-409.

Whitaker, B., T. Solomos, and D. Harrison. 1997. Quantification of $\alpha$-farnesene and its conjugated trienol oxidation products from apple peel by $\mathrm{C} 18$ HPLC with UV detection. J. Agric. Food Chem. 45:760-765.

Whitaker, B. 1998. Phenolic fatty-acid esters from the peel of 'Gala' apples and their possible role in resistance to superficial scald. Postharvest Biol. Technol. 13:1-10.

Whitaker, B., J. Nock, and C. Watkins. 2000. Peel tissue $\alpha$-farnesene and conjugated trienol concentrations during storage of 'White Angel' $x$ 'Rome Beauty' hybrid apple selections susceptible and resistant to superficial scald. Postharvest Biol. Technol. 20:231241.

Zanella, A. 2003. Control of apple superficial scald and ripening-a comparison between 1-methylcyclopropene and diphenylamine postharvest treatments, initial low oxygen stress and ultra low oxygen storage. Postharvest Biol. Technol. 27:69-78. 